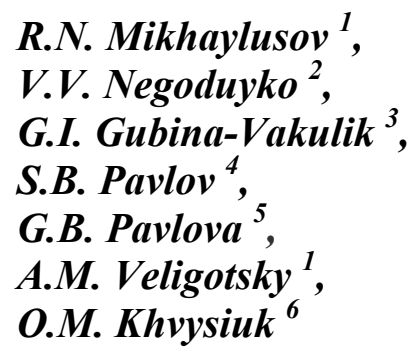

\title{
MORPHOLOGICAL FEATURES OF THE SIMULATED GUNSHOT WOUNDS OF RABBITS' SOFT TISSUES AT DIFFERENT TEMPERATURES OF INJURING OBJECT
}

Kharkiv Medical Academy of Postgraduate Education

Department of Endoscopy and Surgery ${ }^{l}$

Central Research Laboratory ${ }^{4}$

Department of Clinical Laboratory Diagnostics ${ }^{5}$

Department of Traumatology, Anesthesiology and Military Surgery ${ }^{6}$

Amosova str., 58, Kharkov, 61176, Ukraine

e-mail:office@med.edu.ua

Military medical clinical center of the Northern region ${ }^{2}$

Kulturu str., 5, Kharkiv, 61058, Ukraine

e-mail:vmkc@kh.ua

Kharkiv National Medical University ${ }^{3}$

Department of Pathological Anatomy

Nauka av., 4, Kharkiv, 61022, Ukraine

e-mail:meduniver@knmu.kharkov.ua

Харківська медична академія післядипломної освіти

кафедра ендоскопї та хірургї ${ }^{l}$

(зав. - д. мед. н., проф. О.М. Велігоцький)

Центральна науково-дослідна лабораторія ${ }^{4}$

(зав. - д. біол. н., с.н.с. С.Б. Павлов)

кафедра клінічної лабораторної діагностики ${ }^{5}$

(зав. - д. мед. н., проф. Ю.І. Ткач)

кафедра травматологї, анестезіологї та військової хірургії

(зав. - д. мед. н., проф. В.Г. Ринденко)

вул. Амосова, 58, Харків, 61176, Україна

Військово-медичний клінічний иентр Північного регіону ${ }^{2}$

(керівник-полковник мед. служби Ю.В. Подолян)

вул. Культури, 5, Харків, 61058, Україна

Харківський національний медичний університет ${ }^{3}$

кафедра патологічної анатомії

(зав. - д. мед. н., проф. I.В. Сорокіна)

пр. Науки, 4, Харків, 61022, Україна

\author{
Цитування: Медичні перспективи. 2021. Т. 26, № 1. С. 201-209 \\ Cited: Medicni perspektivi. 2021;26(1):201-209
}

Key words: soft tissue, gunshot wound, modeling, temperature factor, pathomorphosis

Ключові слова: м'які тканини, вогнепальне поранення, моделювання, температурний фактор, патоморфоз

Ключевые слова: мягкие ткани, огнестрельное ранение, моделирование, температурный фактор,

патоморфоз

\begin{abstract}
Morphological features of the simulated gunshot wounds of rabbits' soft tissues at different temperatures of injuring object. Mikhaylusov R.N., Negoduyko V.V., Gubina-Vakuli G.I., Pavlov S.B., Pavlova G.B., Veligotsky A.M., Khvysiuk O.M. The article presents the results of experimental modeling of superficial fragment gunshot wounds of soft tissues, obtained in low-energy gunshot wounds. The pathomorphosis of gunshot wounds was studied, and the features and timing of their healing were compared depending on the temperature of the damaging fragments. The aim of the work was to study the effect of the temperature of the injuring shrapnel on the healing processes of the soft tissues of experimental animals with superficial low-energy fragment gunshot wounds. Using the random number method, laboratory animals (rabbits) were divided into 3 experimental groups (15 animals each). In each group, wounding was with fragments with different temperatures $-18^{\circ} \mathrm{C}, 50^{\circ} \mathrm{C}$ and $100^{\circ} \mathrm{C}$. The control group consisted of 10 intact animals. On day 14th, 30th and 60th, 5 animals from each group were withdrawn from the
\end{abstract}


experiment. Microscopic examination of soft tissues was performed using a PRIMO STAR light microscope (Carl Zeiss, Germany) at magnification by 56 and 400 times. When assessing the state of tissues in the area of wound damage, it was established that as the temperature of the injuring fragment increases, a slower filling of the defect formed by the necrotic detritus in the process of utilization of necrotic detritus is observed. The high temperature of the injuring fragment along with the mechanical rupture of tissues causes thermal coagulation necrosis. Dense coagulated necrotic masses covering the wound canal from the inside, not only increase the volume of necrotic masses, but also complicate the process of wound healing. At a temperature of wounding fragments $100^{\circ} \mathrm{C}$, the formation of a necrotic crust on the surface of the wound occurred on average $3 \pm 1.2$ days later than at temperatures of $18^{\circ} \mathrm{C}$ and $50^{\circ} \mathrm{C}$, the least pronounced healing took place at the bottom of the wound and in the muscle tissue. Microscopically necrotic, not dystrophic changes were observed in myocytes. Thus, a comparative analysis of the pathomorphosis of soft tissues in a wound when injured from an air rifle MP-532 with different temperature of the fragments showed differences from both the alteration of the tissues and the regenerative potential.

Реферат. Морфологічні особливості модельованої вогнепальної рани м'яких тканин кроликів при різних температурах травмуючого об'скта. Михайлусов Р.Н., Негодуйко В.В., Губіна-Вакулик Г.І., Павлов С.Б., Павлова Г.Б., Велігоцький О.М., Хвисюк О.М. У статті представлені результати експериментального моделювання поверхневих осколкових вогнепальних поранень м'яких тканин, отриманих при малоенергетичних вогнепальних пораненнях. Вивчено патоморфоз вогнепальних поранень, зіставлені особливості та терміни їх загоєння залежно від температури уражаючих фрагментів. Метою роботи було вивчення впливу температури травмуючого осколка на прочеси загоєння м'яких тканин експериментальних тварин 3 поверхневими осколковими вогнепальними пораненнями з низьким рівнем енергії. Використовуючи метод випадкових чисел, лабораторних тварин (кролики) розподілили на 3 експериментальні групи (по 15 тварин у кожній). У кожній групі травми наносилися осколками з різними температурами $-18^{\circ} \mathrm{C}, 50^{\circ} \mathrm{C} i 100^{\circ} \mathrm{C}$. Контрольна група складалася з 10 інтактних тварин. На 14, 30 і 60 день по 5 тварин з кожної групи були виведені з експерименту. Мікроскопічне дослідження м'яких тканин проводилося з використанням світлового мікроскопа PRIMO STAR (Carl Zeiss, Німеччина) при збільшенні в 56 і 400 разів. При оцінці стану тканин у зоні пошкодження встановлено, щзо з підвищенням температури ранячого осколка спостерігається більш повільне заповнення грануляційною тканиною дефекту, щзо утворюється в процесі утилізації некротичного детриту. Висока температура ранячого осколка поряд з механічним розривом тканин викликає термічний коагуляційний некроз. Щільні коагульовані некротичні маси, щзо покривають рановий канал зсередини, не тільки збільшують обсяг некротичних мас, але й ускладнюють прочес загоєння рани. При температурі ранячих осколків $100^{\circ} \mathrm{C}$ утворення некротичної кірки на поверхні рани відбувалося в середньому на $3 \pm 1,2$ добу - пізніше, ніж при температурах $18^{\circ} \mathrm{C}$ i 50 $\mathrm{C}$, найменш виражене загоєння відбувалося на дні рани $і$ в м'язовій тканині. Мікроскопічно спостерігали некротичні, а не дистрофічні зміни міоцитів. Таким чином, порівняльний аналіз патоморфозу м'яких тканин у рані при пораненні з пневматичної гвинтівки МР-532 з різною температурою осколків показав відмінності як з боку альтерації тканин, так $і$ з боку регенераторного потенціалу.

Despite the active development of vulnerology (the science of wound healing), the deepening of ideas about the pathogenesis of gunshot wounds, the development of new concepts of strategy and tactics for assisting victims, the treatment of gunshot wounds of soft tissues continues to be a pressing surgical problem $[6,13]$. Modern authors have noted an increase in the severity, trauma, multiplicity and combination of injuries resulting from gunshot wounds [14].

Along with this, it is known that from $10 \%$ to $30 \%$ of gunshot wounds of soft tissues do not need surgical treatment and heal well enough. Most often, these are superficial, punctate gunshot wounds, without significant damage $[1,9]$. Usually they are applied to injuring objects with low kinetic energy, that is, not at high speed or with a small mass of bullet or splinter [8].

Thermal exposure is usually not given enough attention, although it is known that it has a significant impact on the pathogenesis of the wound process [12]. To study the effect of the temperature factor on soft tissue damage and the further course of the wound process during superficial low-energy gunshot wounds of the soft tissues, this experimental work was planned and carried out.

The aim of the work is to study the effect of the temperature of the injuring frags on the healing processes of the soft tissues of experimental animals with superficial low-energy fragment gunshot wounds.

\section{MATERIALS AND METHODS OF RESEARCH}

Biological vital modeling of surface fragment gunshot wounds was performed on laboratory animals (rabbits). The features of the pathomorphosis of gunshot wounds, the time of healing of gunshot wounds received low-energy gunshot in wounds were studied. As a biological model for the study of injuries were used rabbits males of the same line (Shinshilla breed) in the amount of 55 individuals, of the same age (7 months), weighing 2600-3600 grams. 
This study was funded by the Ministry of Health of Ukraine from the state budget. The experiments were conducted in accordance with the principles of the "European Convention for the Protection of Vertebrate Animals used for Experimental and Other Scientific Purposes" (Strasbourg, 1986) [5]. Methods of conducting experiments on animals, methods of anesthesia and the deprivation of life of animals complied with European and international ethical standards $[4,7]$.

Research protocols of using laboratory animals were approved by the local ethics committee of the Military medical clinical center of the Northern region (positive decision of the Ethics Commission of the Military medical clinical center of the Northern region No. 3/2 of March 12, 2015, "On the research of soft tissue gunshot wounds using laboratory animals"). Anesthesia with nalbuphine at a dose of $0.3 \mathrm{mg} / \mathrm{kg}$ of animal body weight, intramuscularly was introduced to all laboratory animals 20 minutes before the experiments.

Wounding was carried out from an air rifle, model MR-532, caliber $4.5 \mathrm{~mm}$, the initial velocity of the fragment $140-173 \mathrm{~m} / \mathrm{s}$. The shots were made in the previously shaved rabbit's thigh with steel fragments (fragments of steel wire with sharp uneven edges, weighing $0.5 \pm 0.05$ grams with a temperature $\left(18^{\circ} \mathrm{C}\right.$, $50^{\circ} \mathrm{C}, 100^{\circ} \mathrm{C}$ ).

Weighing fragments was carried out using a Libra digital scale (0.01-100 grams) Leuchtturn (Germany). The fragments were heated immediately before the shot, the temperature of the fragment was monitored using an IPTIC $2000 \mathrm{C}$ remote thermograph (Russia), and the uniformity of the fragment was heated using a Fluke Ti125 thermal imager (USA). The wounds were blind; the fragments remained in the soft tissues of the animals, the wounds healed with fragments.

The division of rabbits into groups was performed by the method of random numbers. Group 1 comprised 15 rabbits (wounds were caused with splinters with a temperature of $18^{\circ} \mathrm{C}$ ), group 2 - 15 rabbits (wounds were caused with splinters with a temperature of $50^{\circ} \mathrm{C}$ ), group $3-15$ rabbits (wounds were caused with splinters with a temperature of $100^{\circ} \mathrm{C}$ ). 5 rabbits from each of these experimental groups were removed from the experiment in 14, 30 and 60 days after the injuries. Group 4 control one -10 rabbits, experiments were not conducted on them, they were kept in the vivarium under the same conditions as the rabbits of the 3 previous groups during the experiment.

To ensure comparability of the results, we used classical methods for preparing histological preparations. Pieces of soft tissues were fixed in $40 \%$ neutral formalin and subjected to paraffin wiring according to the method adopted in the work of autopsy laboratories [2]. After paraffin wiring, sections were made 5-6 microns thick, were stained with hematoxylin-eosin, and also according to the method of Van-Gieson. The condition of the soft tissues was evaluated in a PRIMO STAR light microscope (Carl Zeiss, Germany) with magnification of 56 and 400 times.

\section{RESULTS AND DISCUSSION}

In the 1st group of animals (the temperature of the wounding fragment $18^{\circ} \mathrm{C}$ ) immediately after wounding the wound was $0.4 \times 0.3 \mathrm{~cm}$ in size with smooth edges. On day 2 after injury, a scab was formed. On day 6 after the injury, the wound healed under a scab, a thin, tender, immature scar formed. On day 14 after the injury, the wound healed without surgical treatment, without stitches, by first intention with a gentle, thin, well-visualized scar of $0.2 \times 0.3 \mathrm{~cm}$, without signs of inflammation around the scar.

On day 14, in the area of tissue removed from the area of the wound canal, scar tissue with thin and thick collagen fibers was found, some of the morphofunctional active fibroblasts have already become mature fibrocytes. In the inner layers of granulation tissue (relatively to the wound canal) there is a small lymphocytic infiltration. In the outer sections, fragmented muscle fibers can be seen in the thickness of the granulation tissue (Fig. 1 a).

Macrophage-lymphocytic infiltration is also in the interstitium of the muscle tissue around the forming scar. The proliferation of nuclei in myocytes is noted.

Subsequent observations showed that on the 30th day after the injury there was a complete scarring of the wound. In the depth of the focus of damage during the coloring of the micro-specimen according to Van Gieson, it is clearly seen that the muscle has an elongated scar of parallelly arranged collagen fibers, but there is a lot of fine black "dust". The scar is enclosed in a dense collagen capsule.

For 60 days after injury, the integuments at the wound site are intact. The scar is distinguishable with great difficulty in bright lateral illumination in the form of a thin strip - a scar, measuring from 0.4 $\mathrm{cm}$ to $0.1 \mathrm{~cm}$ and having a lighter color than the skin. Histologically revealed that in the thickness of the dermis is a dense scar, in which there are black inclusions of soot accompanied by macrophage-lymphocytic infiltration (Fig. 1 b).

In the deep sections, where the wound damage to the muscle tissue occurred, a scar was also formed of mature collagenized connective tissue with smooth edges and parallel collagen fibers, with the inclusion of myocytes on the periphery of the scar (Fig. 1 c). 


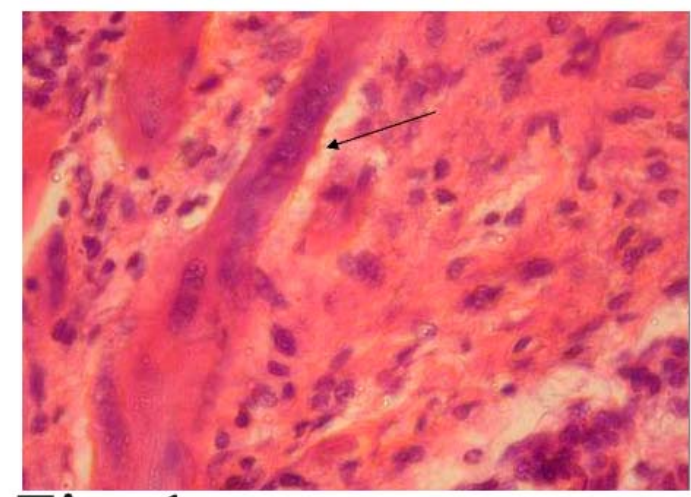

Fig. 1a

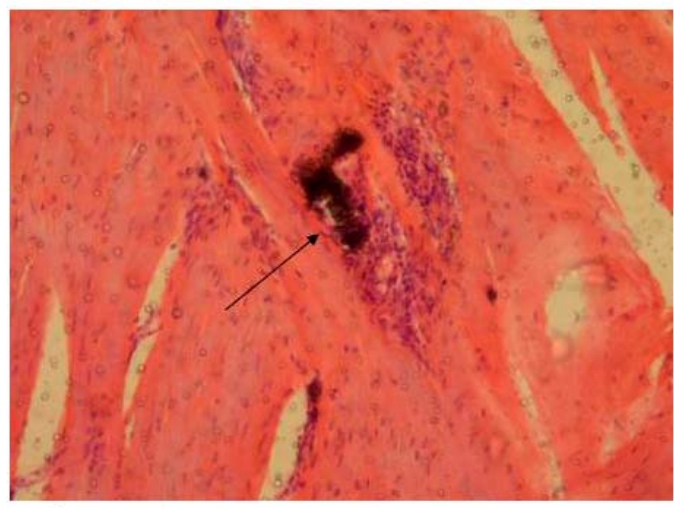

Fig. 1c

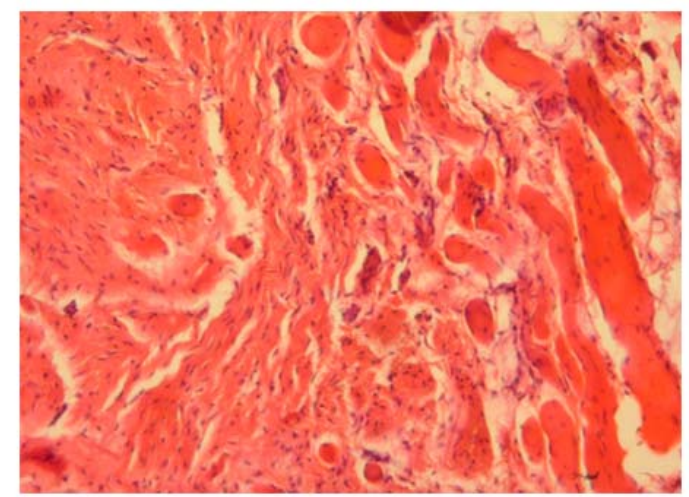

Fig. 1b

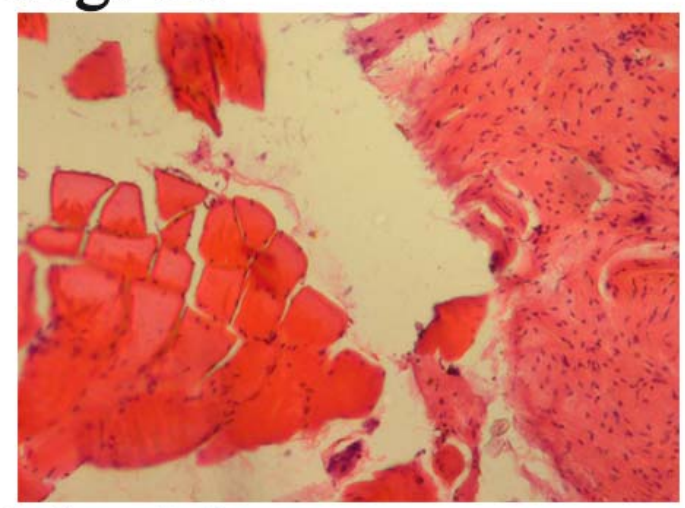

Fig. 1d

Fig. 1 a. Wound canal on day 14 after a fragment wounding at a $t=18^{\circ} \mathrm{C}$. In the depth of the wound - a mature granulation tissue, interspersed with fragments of dystrophic and necrotic modified muscle fibers. In the latter, proliferation of nuclei is noted. Stained with hematoxylin-eosin. 400 times magnification;

$1 \mathrm{~b}$. Wound area on day 60 after fragment wounding at a $\mathrm{t}=18^{\circ} \mathrm{C}$. An irregularly shaped fragment was found in the mature scar, accompanied by macrophage-lymphocytic infiltration.

Stained with hematoxylin-eosin. 400 times magnification;

1 c. Wound canal on day 60 after fragment wounding at a $t=18^{\circ} \mathrm{C}$. Middle part of the wound canal after healing: contact of the scar and muscle tissue. Stained with hematoxylin-eosin. 100 times magnification;

$1 \mathrm{~d}$. Wound canal on day 60 after fragment wounding at a $t=18^{\circ} \mathrm{C}$. In the depth of the wound canal is a fragile contact between the scar and muscle tissue. Stained with hematoxylin-eosin. 100 times magnification

It draws attention that the scar and muscular tissue are probably not firmly connected, because during the dehydration of the sample during the preparation of the micropreparation there was a gap between the scar and the surrounding muscular tissue (Fig. $1 \mathrm{~d}$ ).

When conducting an experimental study in group 2 of animals, the temperature of the wounded fragment was 50 degrees Celsius. Immediately after injury, the wound was $0.5 \times 0.5 \mathrm{~cm}$ in size, with smooth edges. On day 2 after injury, a scab was formed. On the 7th day after the injury, the wound healed under a scab, and a thin, tender, immature scar formed.

On the 14th day after the injury, clinically the wound as well as at the temperature of the injuring fragment at a 18 degrees Celsius healed without surgical treatment, without stitches, by primary tension with a thin well-visualized scar of $0.3 \times 0.4$ $\mathrm{cm}$, there were no signs of inflammation around the scar. It is clearly seen on the micropreparation that on the 14th day after the injury the epidermis was restored, and under it in the wound area there is a young connective tissue, in which there are many fibroblasts, a small presence of fibrocytes and macrophages (Fig. 2 a).

Under the reconstructed layer of the epidermis and the superficial layer of the dermis, the wound canal is elongated, filled with dystrophically modified adipose tissue with membranes of fat cells without nuclei, not completely filled with granulation tissue. In depth at the level of the muscular layer, the direction of the wound canal has changed. Thin, randomly arranged collagen fibers, hard rounded particles, and hair fragments are visible in the lumen of the wound canal (Fig. 2 b). 


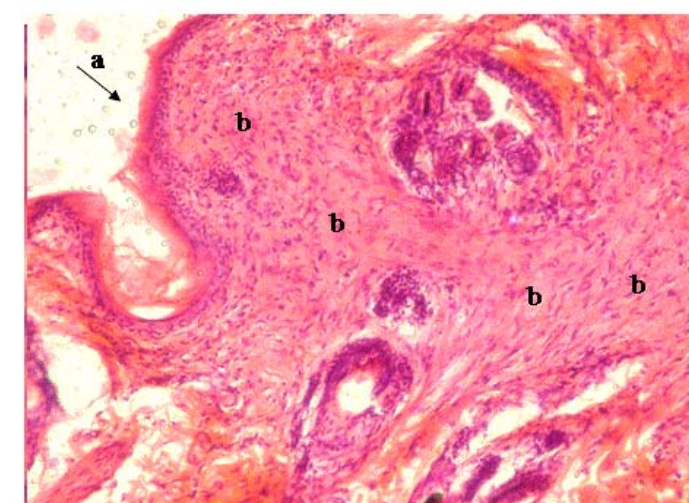

Fig. $2 a$

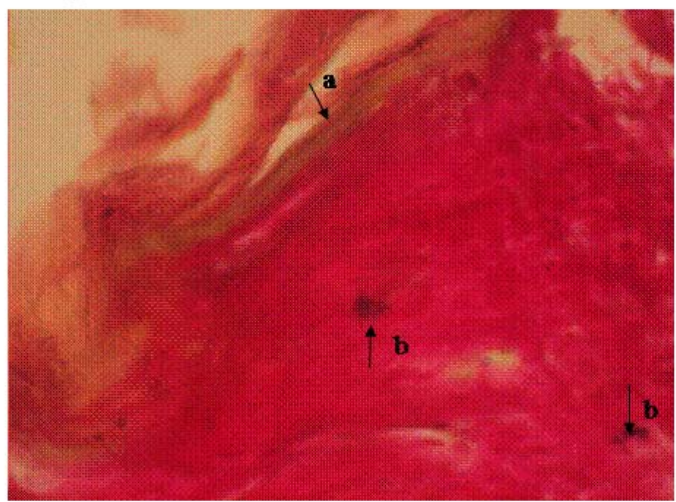

Fig. 2c

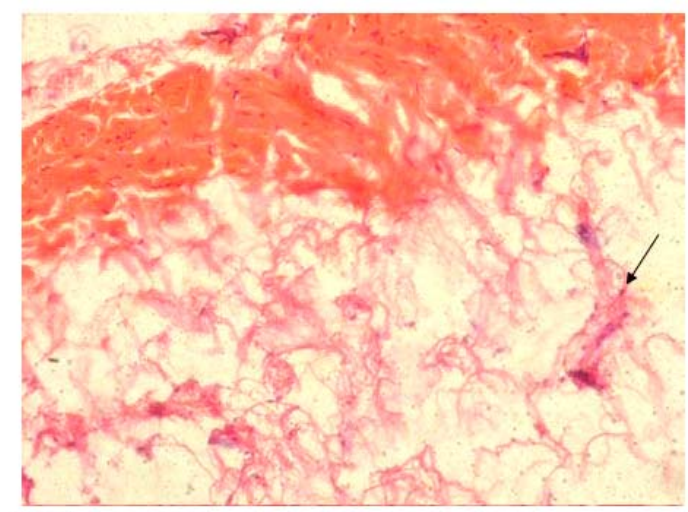

Fig. $2 b$

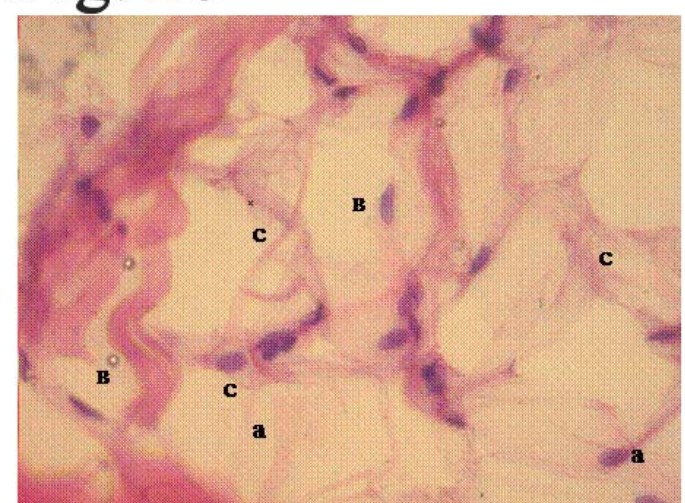

Fig. 2d

Fig. 2 a. Skin on day 14 after a fragment wounding at a $t=50^{\circ} \mathrm{C}$. The epidermis is restored (a), in the dermis - a scar of fresh connective tissue (b). Stained with hematoxylin-eosin. 100 times magnification;

$2 \mathrm{~b}$. Wound canal on day 14 after fragment wounding at a $t=50^{\circ} \mathrm{C}$. In the depth of the wound adipose tissue with pronounced dystrophic changes, devoid of nuclei. Collagen fibers (a) and single capillaries (b).

Staining by Van Gieson 100 times magnification;

2 c. Skin on day 30 after a fragment wounding at a $t=50^{\circ} \mathrm{C}$. Smooth epidermis over the scar (a). In the thickness of the scar - small fragments (b). Staining by Van Gieson. 100 times magnification;

$2 \mathrm{~d}$. Wound on day 30 after fragment wounding at a $\mathrm{t}=50^{\circ} \mathrm{C}$. In the wound canal adipose tissue with loosely lying fibroblasts (a) and monocytes with signs of regeneration (b) of newly formed capillaries, collagen fibers (c). Stained with hematoxylin-eosin. 400 times magnification

On day 30 after the injury at a temperature of the fragment wounding $50^{\circ} \mathrm{C}$, difficult to see a thin scar measuring $0.2 \times 0.4 \mathrm{~cm}$ was noted at the wound site, visual signs of inflammation around the scar were absent.

Microscopically: the level of the surface of the epidermis over the scar is slightly lower compared to intact skin. The thickness of the epidermis is similar to that in intact areas, but the surface is smoother (Fig. 2 c).

When stained by Van Gieson the scar with paralleltwisted, thick collagen fibers is determined in the dermis. Few black grainy soot inclusions were found in the scar tissue. There are no hair follicles in the nearby dermis. However, proliferating keratinocytes are visible in the lower part of one of the most closely located follicles, i.e. hair regrowth occurs.
In the deep layers of the wound, the scar tissue continues to grow, but this process is slow (Fig. 2 d).

In 60 days after injury, the animal was removed from the experiment. In the place of the wound integuments are whole, the scar is difficult to see, with bright side lighting, in the form of a thin strip. A scar from $0.4 \mathrm{~cm}$ to $0.1 \mathrm{~cm}$ has a lighter color than the surrounding skin.

Microscopically, the scar tissue in the wound canal was found to be loose, not compact, that is, with voids. In the depth of the former wound canal, the scar tissue is more mature and closer to the surface - less mature, because it contains much more fibroblasts than fibroblasts. This indicates that the collagen formation in the scar of the wound canal is incomplete.

In the lowermost part of the wound canal in the destruction of muscle tissue the scar is mature (Fig. 3 a). 


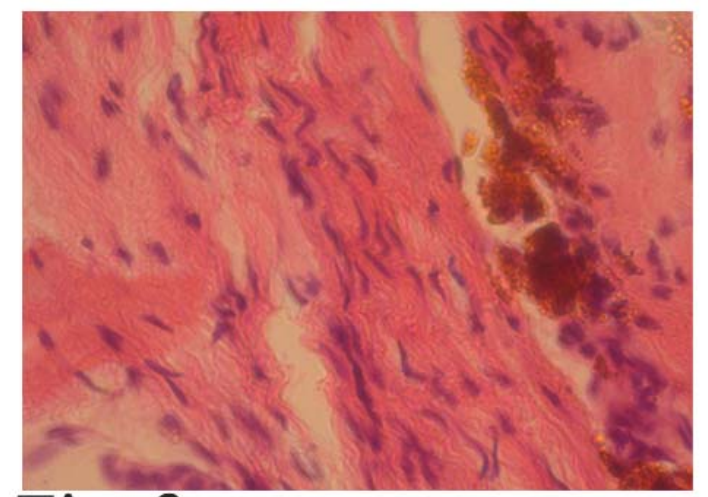

Fig. 3a

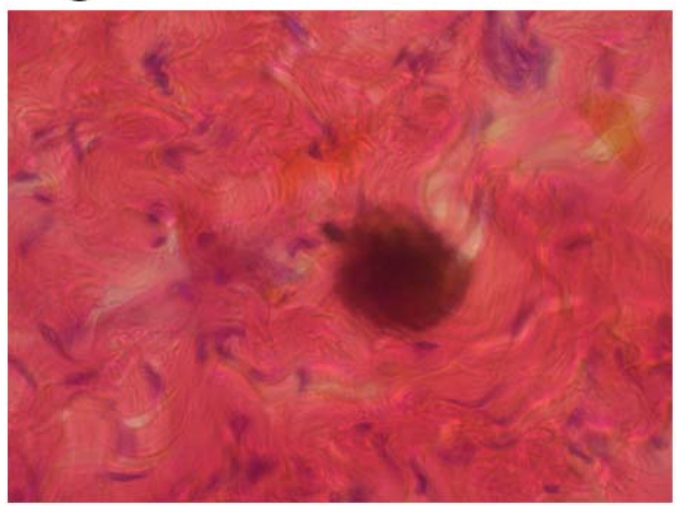

Fig. 3c
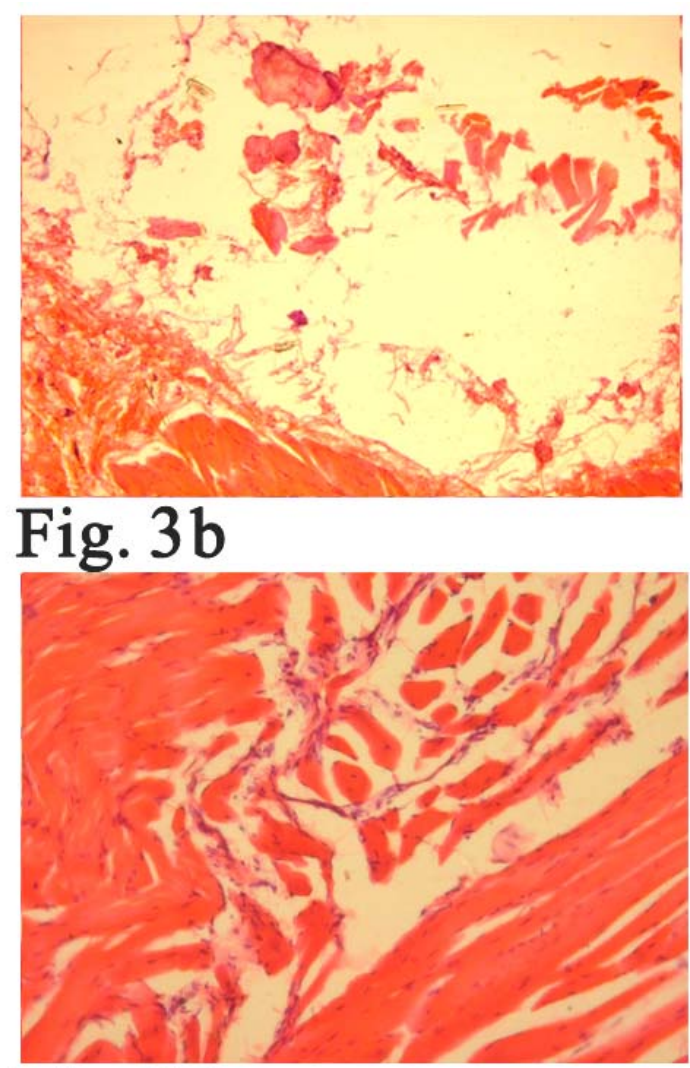

Fig. 3d

Fig. 3 a. Wound canal on day 60 after fragment wounding at a $t=50^{\circ} \mathrm{C}$. Mature connective tissue in place of dead muscle tissue. Brown pigment from soot, both in the cytoplasm of macrophages and lying freely.

Stained with hematoxylin-eosin. 400 times magnification;

3 b. Muscle tissue on day 14 after fragment wounding at a $t=100^{\circ} \mathrm{C}$. The bottom of the wound canal after disposal of necrotic detritus. Stained with hematoxylin-eosin. 100 times magnification;

3 c. Wound canal 30 days after a fragment wounding at a $t=100^{\circ} \mathrm{C}$. Immature connective tissue of the bottom of the wound canal with the inclusion of the rounded shape of a metal fragment.

Stained with hematoxylin-eosin. 400 times magnification;

3 d. Muscle on day 60 after fragment wounding at a $t=100^{\circ} \mathrm{C}$. The presence of a large number of dystrophic and necrotic modified fragmented muscle fibers. Stained with hematoxylin-eosin. 100 times magnification

In the scar tissue there are many fragments of damaged myocytes. The orientation of collagen in the scar tissue is not clear. Scar contact with the muscle in this area of the former wound canal is preserved to a greater extent than on day 30 of the study.

In the 3rd group of animals during the experiment, the temperature of the injuring fragment was $100^{\circ} \mathrm{C}$. Immediately after the injury, the wound measured $0.5 \times 0.4 \mathrm{~cm}$, and the edges were even. On day 3 after injury, a scab was formed. On day 8 after the injury, the scab fell away, revealing a thin, tender, immature scar. On day 14 after the injury, the integuments are whole, the wound has healed without surgical treatment, without stitches, by primary intention with a delicate, well-visualized scar with a size of $0.3 \times 0.4 \mathrm{~cm}$. Visually there are no signs of inflammation around the scar.
Microscopic examination of tissue from the wound area on day 14 after injury found that the epidermis recovered with signs of epithelial cell hyperproliferation, since the thickness of the epidermis in the area of the former wound was increased. The wound canal at the bottom, i.e. at its bottom, has a oblong cavity, not filled with granulation tissue (Fig. 3 b).

On the walls of this cavity, capillaries and fibroblasts between necrotic muscle tissue fragments are clearly visible. Some of the dead muscle fibers have signs of coagulation, as a result of primary alteration due to the effect of high temperature.

The bottom of the described cavity is represented by a scar tissue with a large number of small black inclusions. And in perivascular areas of immature granulation tissue there are accumulations of 
macrophages and lymphocytes. In the cytoplasm of macrophages, one can see fine black grains formed as a result of phagocytosis of soot particles.

On day 30 after injury at the wound site, there was a macroscopically difficult to see thin scar, measuring $0.2 \times 0.4 \mathrm{~cm}$, without visual signs of inflammation around it.

Microscopically, it was found that the wound canal in the thickness of the muscle tissue is filled with dense scar tissue with metal inclusions that look more rounded than at lower temperatures of the wound fragment and without tissue reaction (Fig. $3 \mathrm{c}$ ).

However, deep in the muscle, the wound canal is not covered with connective tissue, but is empty, i.e. on day 30 after the injury, the wound canal is a connective tissue capsule of an oblong shape and with a cavity inside. On day 60 after the injury with the temperature of the injuring fragment $100^{\circ} \mathrm{C}$, the animal was derived from the experiment: in the wound site the integuments are whole, the scar is difficult to distinguish in a bright side lighting, in the form of a thin strip. Scar size from $0.3 \mathrm{~cm}$ to $0.2 \mathrm{~cm}$ lighter in color than the color of the surrounding skin.

Microscopically it is established that the scar tissue has a loose appearance, with distanced collagen fibers, the main substance with a predominance of glycosaminoglycans.

At the site of wound penetration into the muscle tissue along the periphery of the scar, fragmented myocytes are surrounded by layers of mature connective tissue (Fig. $3 \mathrm{~d}$ ).

Thus, a comparative analysis of the pathomorphosis of soft tissues in a wound when injured from an air rifle MP-532 with different temperature of the fragments showed differences, both from the alteration of tissues and from the possibilities of regeneration.

A gunshot wound with a fragment temperature of $18^{\circ} \mathrm{C}$ causes less damage to the tissue. This is evidenced by the smaller size of gunshot wounds and weak, but preserved, possibilities for regeneration on the part of all types of tissues, especially muscle tissue, where, despite the absence of transverse and longitudinal striation and fragmentation of myocytes, the possibility of proliferation remains.

At a temperature of fragments of $50^{\circ} \mathrm{C}$, there was a more pronounced tissue damage than at a temperature of $18^{\circ} \mathrm{C}$, as evidenced by the large size of wounds. A necrotic-hemorrhagic crust on the surface of the wound was formed on day 2 , at the temperature of the wounded fragments of $18^{\circ} \mathrm{C}$, but it was rejected on day 7 , that is, 1 day later than at the temperature of the wounded fragments of $18^{\circ} \mathrm{C}$. It was established that on day 60 after being wounded with a pneumatic weapon, in the wound fibrillogenesis processes in the scar tissue fully completed. Necrotized myocytes were detected, no signs of regeneration were detected.

At a temperature of the wounded fragments of $100^{\circ} \mathrm{C}$, the formation of a necrotic crust on the surface of the wound occurred 1 day later than at temperatures of $18^{\circ} \mathrm{C}$ and $50^{\circ} \mathrm{C}$. At the temperature of the fragments of $100^{\circ} \mathrm{C}$, the least pronounced healing took place at the bottom of the wound, in the muscle tissue. Microscopically, necrotic, and not dystrophic changes in myocytes were observed, which is associated with the high temperature of the fragments that caused coagulation necrosis.

The mechanisms and severity of soft tissue injuries from gunshot wounds have been reported in several articles $[3,10,11]$. However, none of these previous studies had examined the effect of the temperature of the injuring fragment on the healing processes of the soft tissues.

In our work, microscopic examination of the tissues in the area of wound damage revealed that with increasing temperature of the injuring fragment, a slower filling of the defect formed in the process of utilization of necrotic detritus by granulation tissue is observed. As a result, on day 60 after the injury, at a temperature of the wounded fragment of $50^{\circ} \mathrm{C}$ and $100^{\circ} \mathrm{C}$, in the upper part of the wound canal, areas of loose ripening granulation tissue were found, and at $100^{\circ} \mathrm{C}-$ to a greater extent, while at $18^{\circ} \mathrm{C}$ - already formed dense scar was detected.

Thus, when modeling surface fragmentation of gunshot wounds, the high temperature of the injuring fragment along with the mechanical rupture of the tissue causes thermal coagulation necrosis. At the same time, dense coagulated necrotic masses cover the wound canal from the inside, not only increasing the volume of necrotic masses, which must be removed for faster healing, but also making it difficult for the wound to heal. Due to the fact that by the 60th day of observation fragments, dystrophic and necrotic-altered tissues remained in the wounds, a fibrous capsule with disturbed trophism and vascularization was formed around the wound canal, delaying the processes of repair and regeneration.

\section{CONCLUSIONS}

Experimental studies of low-kinetic surface fragmentation of gunshot wounds at different temperatures of the injuring projectile showed that they do not need surgical treatment, and in experimental animals heal without any treatment. The revealed morphological differences in the healing of gunshot wounds of soft tissues with different temperatures of the injuring fragment show that longer healing of the gunshot wounds of soft tissues is observed when fragments with a temperature of $100^{\circ} \mathrm{C}$ are injured compared to 
fragments of $50^{\circ} \mathrm{C}$ and $18^{\circ} \mathrm{C}$, due to the severity of coagulation necrosis phenomena, a longer disturbance of trophism and vascularization, which leads to a delay in the processes of repair and regeneration.
Conflict of interests. The authors declare no conflict of interest.

\section{REFERENCES}

1. Belenkiy VA, Negoduiko VV, Mikhailusov RN [A new approach to the revision of gunshot wounds]. Problemy viiskovoi okhorony zdorovia. 2016;45(1):290295. Russian.

2. Merkulov GA. [Pathohistological technique course]. 5th edition corrected and updated. Leningrad: Medgiz, 1969. p. 423. Russian.

3. Breeze J, Sedman AJ, James GR, Newbery TW, Hepper AE. Determining the wounding effects of ballistic projectiles to inform future injury models: a systematic review. J R Army Med Corps. 2014;160(4):273-8. doi: https://doi.org/10.1136/jramc-2013-000099

4. Directive 2010/63/EU of the European parliament and of the Council of 22 September 2010 on the protection of animals used for scientific purposes. Official Journal of the European Union. Available from: http://eur-lex.europa.eu/legal-

content/EN/TXT/?uri=CELEX:32010L0063

5. European Convention for the Protection of Vertebrate Animals used for Experimental and other Scientific Purposes. ETS No. 123, Strasbourg; 1986. p. 11. Available from:

https://www.coe.int/en/web/conventions/full-list/-/conventions/treaty/123

6. Gonzalez AC, Costa TF, Andrade ZA, Medrado A.R. Wound healing - A literature review. An Bras Dermatol. 2016;91(5):614-20.

doi: https://doi.org/10.1590/abd1806-4841.20164741

7. Guide for the Care and Use of Laboratory Animals, 8th edition. National Research Council (US) Committee for the Update of the Guide for the Care and
Use of Laboratory Animals.Washington (DC): National Academies Press (US); 2011. p. 246

8. Lightweight Ballistic Composites 2nd Ed. Ashok Bhatnagar, editor. Woodhead Publishing; 2016. 482 p.

9. Stadler F, Shaban RZ, Tatham P. Maggot Debridement Therapy in Disaster Medicine. Prehosp Disaster Med. 2016;31(1):79-84.

doi: https://doi.org/10.1017/S1049023X15005427

10. Stefanopoulos PK, Filippakis K, Soupiou OT, Pazarakiotis VC. Wound ballistics of firearm-related injuries - part 1: missile characteristics and mechanisms of soft tissue wounding. Int J Oral Maxillofac Surg. 2014;43(12):1445-58.

doi: https://doi.org/10.1016/j.ijom.2014.07.013

11. Stefanopoulos PK, Pinialidis DE, Hadjigeorgiou GF, Filippakis KN. Wound ballistics 101: the mechanisms of soft tissue wounding by bullets. Eur J Trauma Emerg Surg. 2017;43(5):579-86.

doi: https://doi.org/10.1007/s00068-015-0581-1

12. Widgerow AD, King K, Tussardi IT. et al. The burn wound exudate - an under-utilized resource. Burns. 2015;41(1):11-7.

doi: https://doi.org/10.1016/j.burns.2014.06.002

13. Franke A, Bieler D, Friemert B. et al. The First Aid and Hospital Treatment of Gunshot and Blast Injuries. Dtsch Arztebl Int. 2017;114(14):237-43. doi: https://doi.org/10.3238/arztebl.2017.0237

14. Willy C, Hauer T, Huschitt N, Palm HG. "Einsatzchirurgie" - experiences of German military surgeons in Afghanistan. Langenbecks Arch Surg. 2011;396(4):507-22. doi: https://doi.org/10.1007/s00423-011-0760-4

\section{СПИСОК ЛІТЕРАТУРИ}

1. Беленький В. А., Н Негодуйко В. В., Михайлусов Р. Н. Новый подход к ревизии огнестрельных ран. Проблеми військової охорони здоров'я. 2016. Т. 45, № 1. С. 290-295.

2. Меркулов Г. А. Курс патологогистологической техники. 5-е изд., испр. и доп. Л.: Медгиз, 1969. $423 \mathrm{c}$.

3. Determining the wounding effects of ballistic projectiles to inform future injury models: a systematic review / J. Breeze et al. J R Army Med Corps. 2014. Vol. 160, No. 4. P. 273-278.

DOI: https://doi.org/10.1136/jramc-2013-000099

4. Directive 2010/63/EU of the European parliament and of the Council of 22 September 2010 on the protection of animals used for scientific purposes as amended by Regulation (EU) 2019/1010. Official Journal of the European Union. URL: https://eur-lex.europa.eu/legalcontent/EN/TXT/?uri=celex:32010L0063
5. European Convention for the Protection of Vertebrate Animals used for Experimental and other Scientific Purposes. ETS No.123, Strasbourg, 18/03/1986. 11p. URL: https://www.coe.int/en/web/conventions/fulllist/-/conventions/treaty/123 (accessed: 16.04.2019).

6. Gonzalez A. C., Costa T. F., Andrade Z. A., Medrado A. R. Wound healing - A literature review. An Bras Dermatol. 2016. Vol.91, No. 5. P. 614-620. DOI: https://doi.org/10.1590/abd1806-4841.20164741

7. Guide for the Care and Use of Laboratory Animals, 8th ed. National Research Council (US) Committee for the Update of the Guide for the Care and Use of Laboratory Animals. Washington (DC): National Academies Press (US); 2011. 246 p.

8. Lightweight Ballistic Composites 2nd ed. Edited by: Ashok Bhatnagar. Woodhead Publishing, 2016. 482 p.

9. Stadler F., Shaban R. Z., Tatham P. Maggot Debridement Therapy in Disaster Medicine. Prehosp 
Disaster Med. 2016. Vol.31. No. 1. P. 79-84. DOI: https://doi.org/10.1017/S1049023X15005427

10. Stefanopoulos P. K., Filippakis K., Soupiou O. T., Pazarakiotis V. C. Wound ballistics of firearm-related injuries--part 1: missile characteristics and mechanisms of soft tissue wounding. Int J Oral Maxillofac Surg. 2014. Vol. 43, No. 12. P. 1445-1458.

DOI: https://doi.org/10.1016/j.ijom.2014.07.013

11. Stefanopoulos P. K., Pinialidis D. E., Hadjigeorgiou G. F., Filippakis K. N. Wound ballistics 101: the mechanisms of soft tissue wounding by bullets. Eur $J$ Trauma Emerg Surg. 2017. Vol. 43, No. 5. P. 579-586. DOI: https://doi.org/10.1007/s00068-015-0581-1
12. The burn wound exudate - an under-utilized resource / Widgerow A. D. et al. Burns. 2015. Vol. 41, No. 1. P. 11-17.

DOI: https://doi.org/10.1016/j.burns.2014.06.002

13. The First Aid and Hospital Treatment of Gunshot and Blast Injuries / A. Franke et al. Dtsch Arztebl Int. 2017. Vol. 114, No. 14. P. 237-243.

DOI: https://doi.org/10.3238/arztebl.2017.0237

14. Willy C., Hauer T., Huschitt N., Palm H. G. "Einsatzchirurgie" - experiences of German military surgeons in Afghanistan. Langenbecks Arch Surg. 2011. Vol. 396, No. 4. P. 507-522.

DOI: https://doi.org/10.1007/s00423-011-0760-4

The article was received 2020.01 .14 